\title{
In memoriam: Prof. Dr. med. Dr. h.c. W.Straub
}

\section{0-1993}

Use Strempel

Use Strempel

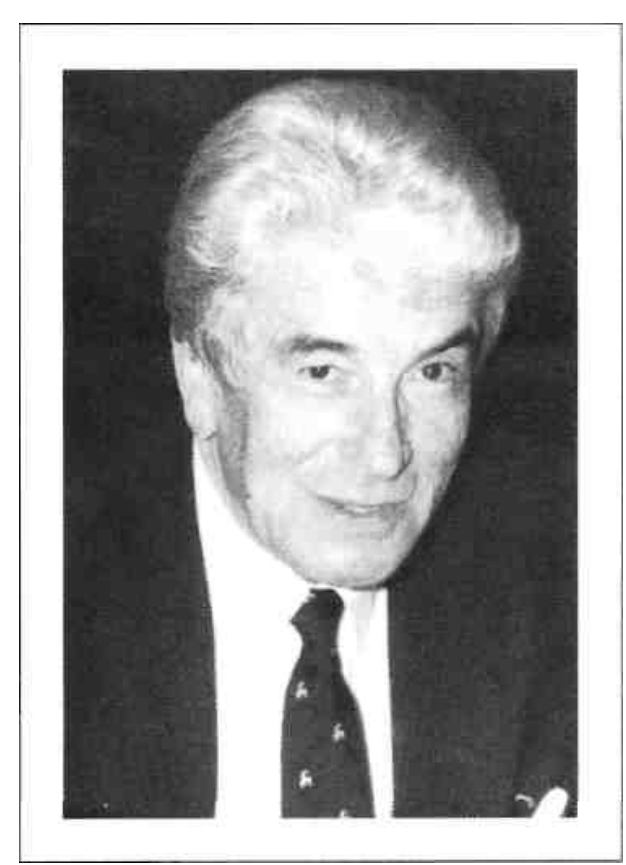

After a short serious illness, Wolfgang Straub, the coordinating editor of Oph-thalmologica for many years, died suddenly and unexpectedly. After his retirement in 1989, he dedicated himself with special enthusiasm to his editorial ophthalmolog-ical work.

Wolfgang Straub was born on December 29,1920, in the Swabian Möttlingen. As a student at the Medical Military Academy of Berlin, he studied medicine in Berlin, and later in Göttingen, Innsbruck, Tubingen, Wroclaw and Munich from 1940 to 1945. He began his oph-thalmological training under Prof. Stock in Tubingen in 1945. As a young up-and-coming assistant medical director, he was sent from Tubingen to Hamburg by Prof. Sautter in 1953, in order to pave the way for Prof. Sautter in his new appointment as medical director. Under the direction of Sautter in Hamburg, he

could further his young scientific career successfully. He habilitated in 1954 and was awarded the Martini prize in 1960.

With his research into toxoplasmosis and his pioneer works in the field of electroretinography, he had become internationally

known in the 1950s already. He won worldwide recognition for his photographic atlases of ophthalmology, translated meanwhile into several languages. 
In 1961, as the youngest professor of ophthalmology, he received a call to the University of Marburg.

165

There, with a short interruption as intermediate director of the University Eye Hospital of Bonn, he directed the fate of the clinic for 28 years. As dean he determined decisively the image of the whole medical faculty from 1968-1969. an extremely difficult time for educational institutes. Prof. Straub attained high recognition at home and abroad: in 1972, he was conferred the title of doctor honoris causa by the French University of Clermont-Ferrand. He was a member of the «Deutsche Ophthal-mologische Gesellschaft» (German Ophthalmological Society) whose president he was in 1976/77 and of the «Société Française d'Ophtal-mologie» that honored him in 1979 by awarding him the «Médaille d'Or Chibret» and appointed him «délégué étranger», representative of the German members of the French society, in 1980.

Further, he was honored with his election as vice president of the 'International Council of Ophthalmology'. In November 1984, he became a member of the famous 'Academia Ophthalmologica Internationalis' counting only 50 ophthalmologists worldwide. Finally, his admission to the «Académie Nationale de Médicine» of France represented an outstanding appreciation of his scientific achievement. Before him, this distinction had only been given to such famous German scientists as Bunsen (1867), Helmholtz (1867), Virchow (1867), Koch (1899), Behring (1900), Röntgen (1900), Hirschberg (1903) and last but not least Merchionini (1961).

On the national level, Prof. Straub was engaged in the scientific advisory board of the Federal General Medical Council, into the managing board of which he was elected in 1980. For many years, he was the speaker of his special scientific field at the national and international congress of further education of the Federal General Medical Council. He was a member of the scientific advisory board of the organ of the German internists Der Internist, in the editorial board of the former von Graefes Archiv fur klinische und experimentelle Opthal-mologie, coordinating editor of Ophthalmologica, editor of Developments in Ophthalmology as well as special editor for ophthalmology of the Deutsches Ä Пteblatt. Moreover, at the Department of Medical Examination Questions in Mainz, he worked for the catalogue of questions in his special field until his death.

His own over 300 national and international publications are evidence of his great scientific activity and proof of his many innovative thoughts and research results.

Before his death, he was working on the new edition of his book Untersuchung-smethoden in der Augen-heilkunde (examination methods in ophthalmology) but had to stop shortly before its completion.

His great charm and his inimitable personality that harmoniously combined leadership qualities and strength of character gave him a charismatic aura. Correctness and determination paired with warmth and friendliness, enriched by his distinct sense of humor and great vivacity, were characteristics of his personality.

That is why everyone who has ever had the pleasure to live and work with him misses him so much. But in their hearts and in his scientific work he lives on for ever.

166

Strempel

Obituary 